\title{
GAMBARAN PENGETAHUAN PASIEN TUBERKULOSIS (TB) PARU TENTANG KEPATUHAN MINUM OBAT DI POLI KLINIK PARU RSUD ARIFIN ACHMAD PROPINSI RIAU
}

\author{
Chairil, Muhammad Azmi
}

\author{
Staf pengajar Jurusan DIII Keperawatan FMIPA dan Kesehatan \\ Alumnus Jurusan DIII Keperawatan FMIPA dan Kesehatan \\ Universitas Muhammadiyah Riau \\ Email: chairil@umri.ac.id
}

\section{ABSTRACT}

Pulmonary tuberculosis is a disease caused by Mycobacterium tuberculosis is transmitted through the air. The purpose of this study was to determine the Knowledge Overview Patients Tuberculosis (TB) Lung About Drugs in Drinking Compliance Poli Lung Clinic Arifin Achmad Riau Province. The type of research is descriptive with the sampling technique is accidental sampling where the sample in this study are some of the respondents in Lung Clinic Arifin Achmad Hospital Riau province amounted to 45 respondents. Tool data collection using questionnaires and data analysis used is univariate. From the research that has been conducted on 21-25 May 2015 showed that the picture of the knowledge of individuals with tuberculosis (TB) in the lungs majority enough category were 26 respondents (57.8\%). Conclusion: Based on the results of these studies are expected in patients with tuberculosis $(T B)$ in the lungs to pay attention to compliance with taking medication so the healing process can be achieved as expected

Kata Kunci: Pengetahuan, Pasien TB Paru, Obat

\section{PENDAHULUAN}

Tuberkulosis paru adalah penyakit yang disebabkan oleh kuman Mycobacteriun tuberculosis yang ditularkan melalui udara (droplet nuclei) saat seorang pasien tuberkulosis batuk dan percikan ludah yang mengandung bakteri terhirup oleh orang lain saat bernapas. Sekali batuk dapat menghasilkan sekitar 3000 percikan dahak. Masa inkubasinya selama 3-6 bulan (Widoyono, 2008).

Pengobatan TB Paru dapat diberikan dalam 2 tahap, yaitu tahap intensif 2 bulan pengobatan dan tahap lanjutan 4-6 bulan berikutnya. Pengobatan yang teratur pada pasien TB Paru dapat sembuh secara total, jika penderita menghentikan pengobatan, kuman TB Paru akan mulai berkembang biak lagi yang berarti penderita mengulangi pengobatan intensif selama 2 bulan pertama (WHO, 2013).

Tanpa pengobatan, setelah lima tahun 50\% dari penderita TB akan meninggal, 25\% akan sembuh sendiri dengan daya tahan tubuh tinggi, dan 25\% sebagai kasus kronik yang tetap menular (Limbu \& Marni, 2007). Sebaliknya, jika penderita melaksanakan pengobatan dengan baik maka dapat menekan angka kematian yang disebakan oleh TB Paru (Muniarsih \& Livana, 2007).

Berdasarkan laporan hasil survei yang dilakukan oleh WHO dari tahun 2008 sampai dengan 2012 di negara-negara di dunia, bahwa penggunaan Directly Observed Treatment Short Course (DOTS) dan strategi stop TB mampu menurunkan beban TB setiap tahunnya. Penggunaan DOTS dan strategi stop TB merupakan pengobatan dengan pengawasan langsung terapi dengan cara membantu pasien mengambil obat secara teratur untuk memastikan kepatuhan pasien dalam pengobatan TB Paru. (WHO, 2013).

Di Indonesia mulai tahun 1995 dengan 5 komponen yaitu komitmen politik kebijakan dan dukungan dana penanggulangan TB Paru, diagnosis TB Paru dengan pemeriksaan secara mikroskopik, pengobatan dengan Obat Anti TB yang diawasi langsung oleh Pengawas Menelan Obat (PMO), ketersediaan obat dan pencatatan hasil kinerja program TB Paru (Kemenkes RI, 2012).

RSUD Arifin Achmad Propinsi Riau merupakan Rumah Sakit rujukan dari beberapa Rumah Sakit yang berada di dalam maupun di 
luar Propinsi Riau. Menurut data dari Medical Record RSUD Arifin Achmad pada tahun 2013 kasus TB paru mencapai 180 jiwa dan pada tahun 2014 kasus TB paru mencapai 107 jiwa. Sedangkan pasien TB yang putus minum obat pada tahun 2013 berjumlah 30 orang $(16,67 \%)$, sedangkan tahun 2014 sebanyak 43 orang $(40,18 \%)$.

Selain itu juga ditemukan data TB MDR (Multi Drug Resisten) yang merupakan lanjutan penyakit TB paru yang diakibatkan salah satunya karena putus obat, dan ditemukan pada tahun 2014 terdapat 14 kasus TB MDR dan tahun 2015 meningkat tinggi menjadi 41 kasus.Menurut hasil survey awal pada tanggal 22 April 2015 di Poli Klinik Paru RSUD Arifin Achmad Propinsi Riau dengan 10 Responden didapatkan bahwa hanya 3 responden (30\%) yang mengerti tentang kepatuhan minum obat pada penderita TB paru, sedangkan yang tidak mengetahui sebanyak 7 responden (70 \%).Dari data di atas makan peneliti tertarik mengambil judul penelitian tentang gambaran pengetahuan pasien tuberkulosis (TB) paru tentang kepatuhan minum obat di Ruangan Paru Terpadu Rsud Arifin Achmad Propinsi Riau.

\section{METODOLOGI PENELITIAN}

Penelitian yang digunakan dalam penelitian ini adalah metode deskriptif, yaitu suatu metode penelitian yang dilakukan dengan tujuan utama untuk membuat gambaran atau deskripsi tentang suatu keadaan secara objektif (Notoatmodjo, 2005). Pada penelitian ini bertujuan untuk memberikan gambaran pengetahuan pasien TB paru tentang kepatuhan minum obat Penelitian ini telah dilaksanakan di Poli Klinik Paru RSUD Arifin Achmad Propinsi Riau Penelitian ini telah dilaksanakan dilaksanakan pada tanggal 01- 07 Mei 2014. Populasi dalam penelitian ini adalah semua jumlah pasien $\mathrm{Tb}$ paru yang sedang di rawat Di Ruang Paru Terpadu Arifin Achmad Propinsi Riau.Sampel dalam penelitian ini adalah dengan teknik pengambilan Accidental Sampling, yang artinya jumlah sampel dipilih hanya berdasarkan ketersediaannya responden yang berada ditempat yang tepat dan diwaktu yang tepat sesuai tujuan penelitian (Dempsey, 2002).

Penelitian ini instrumen yang digunakan adalah kuesioner. Dalam analisa data peneliti menggunakan analisa univariate, yaitu analisis yang dilakukan terhadap variabel yang diteliti. Pada umumnya dalam analisis ini hanya menghasilkan distribusi dan persentase dari tiap variabel.Menurut Notoatmodjo (2003) dalam Kiki Parmanda (2013) dengan melihat persentase data yang dikumpulkan dalam bentuk tabel frekuensi.

\section{HASIL DAN PEMBAHASAN}

Berdasarkan penelitian yang dilakukan pada tanggal 21-25 Mei 2015 di TK Poli Klinik Paru RSUD Arifin Achmad Propinsi Riau, yang beralamat di Hangtuah Pekanbaru dapat diperoleh data-data mengenai pengetahuan Pasien TB Paru tentang kepatuhan minum obat sebagai berikut:

Tabel 1.

Distribusi Frekuensi Responden berdasarkan Jenis Kelamin di Di Poli Klinik Paru RSUD Arifin Achmad Propinsi Riau Mei 2015.

\begin{tabular}{cccc}
\hline \multirow{2}{*}{ No } & $\begin{array}{c}\text { Kategori Jenis } \\
\text { Kelamin }\end{array}$ & $\begin{array}{c}\text { Frekuensi } \\
(\mathrm{f})\end{array}$ & $\begin{array}{c}\text { Persentase } \\
(\%)\end{array}$ \\
\hline 1 & Laki - laki & 36 & 80 \\
2 & Perempuan & 9 & 20 \\
\hline & Total & 45 & 100 \\
\hline
\end{tabular}

Tabel 2.

Distribusi Frekuensi Responden berdasarkan Umur di Poli Klinik Paru RSUD Arifin Achmad Propinsi Riau Mei 2015

\begin{tabular}{clcc}
\hline No & \multicolumn{1}{c}{$\begin{array}{c}\text { Kategori Umur } \\
\text { (Tahun) }\end{array}$} & $\begin{array}{c}\text { Frekuensi } \\
\text { (f) }\end{array}$ & $\begin{array}{c}\text { Persentase } \\
(\%)\end{array}$ \\
\hline 1 & $\begin{array}{l}\text { Dewasa Tengah }(36- \\
\text { 54) }\end{array}$ & 34 & 75,6 \\
2 & Lansia (>55) & 11 & 24,4 \\
\hline \multicolumn{1}{c}{ Total } & 45 & 100 \\
\hline
\end{tabular}

Tabel 3

Distribusi Frekuensi Responden berdasarkan Tingkat Pendidikan di Poli Klinik Paru RSUD Arifin Achmad Propinsi Riau Mei 2015

\begin{tabular}{cccc}
\hline No & Tingkat Pendidikan & $\begin{array}{c}\text { Frekuensi } \\
\text { (f) }\end{array}$ & $\begin{array}{c}\text { Persentase } \\
(\%)\end{array}$ \\
\hline 1 & Rendah & 30 & 24,4 \\
2 & Menengah & 11 & 66,7 \\
3 & Tinggi & 4 & 8,9 \\
\hline & Total & 45 & 100 \\
\hline
\end{tabular}


Tabel 4.

Distribusi Frekuensi Responden Berdasarkan

Pekerjaan di Poli Klinik Paru RSUD Arifin Achmad Propinsi Riau Mei 2015

\begin{tabular}{cccc}
\hline No & Jenis Pekerjaan & $\begin{array}{c}\text { Frekuensi } \\
\text { (f) }\end{array}$ & $\begin{array}{c}\text { Persentase } \\
(\%)\end{array}$ \\
\hline 1 & Wiraswasta & 5 & 11,1 \\
2 & Swasta & 9 & 20,0 \\
3 & Guru & 2 & 4,4 \\
4 & Petani & 7 & 15,6 \\
5 & IRT & 9 & 20,0 \\
6 & Pengangguran & 13 & 28,9 \\
\hline & Total & 45 & 100 \\
\hline
\end{tabular}

Tabel 5.

Distribusi Frekuensi Responden Berdasarkan Informasi yang Pernah Diperoleh Tentang Kepatuhan Minum Obat di Poli Klinik Paru RSUD Arifin Achmad Proponsi Riau Mei 2015

\begin{tabular}{cccc}
\hline No & $\begin{array}{c}\text { Informasi yang } \\
\text { diperoleh }\end{array}$ & $\begin{array}{c}\text { Frekuensi } \\
\text { (f) }\end{array}$ & $\begin{array}{c}\text { Persentase } \\
(\%)\end{array}$ \\
\hline 1 & Ya & 31 & 68,9 \\
2 & Tidak & 14 & 31,1 \\
\hline & Total & 45 & 100 \\
\hline
\end{tabular}

Tabel 6.

Distribusi Frekuensi Responden Berdasarkan Sumber Informasi Tentang Kepatuhan Minum Obat di Poli Klinik Paru RSUD Arifin Achmad Propinsi Riau Mei

\begin{tabular}{cccc}
\multicolumn{4}{c}{2015} \\
\hline No & Sumber Informasi & $\begin{array}{c}\text { Frekuensi } \\
(\mathrm{f})\end{array}$ & $\begin{array}{c}\text { Persentase } \\
(\%)\end{array}$ \\
\hline 1 & Media Cetak & 5 & 16,4 \\
2 & Media Elektronik & 10 & 32,4 \\
3 & Tenaga Kesehatan & 15 & 48,0 \\
4 & Teman Sebaya & 1 & 3,2 \\
\hline & Total & 31 & 100 \\
\hline
\end{tabular}

Tabel 7

Distribusi Frekuensi Responden Berdasarkan Pengetahuan Tentang Kepatuhan Minum Obat di Poli Klinik Paru RSUD Arifin Achmad Propinsi Riau Mei 2015

\begin{tabular}{cccc}
\hline No & $\begin{array}{c}\text { Kategori } \\
\text { Pengetahuan }\end{array}$ & $\begin{array}{c}\text { Frekuensi } \\
(\mathrm{f})\end{array}$ & $\begin{array}{c}\text { Persentase } \\
(\%)\end{array}$ \\
\hline 1 & Baik & 6 & 13,3 \\
2 & Cukup & 26 & 57,8 \\
3 & Kurang & 13 & 28,9 \\
\hline & Total & 45 & 100 \\
\hline
\end{tabular}

Tabel.8

Tabulasi Silang Pengetahuan dengan Informasi

\begin{tabular}{lccccc}
\hline No & $\begin{array}{c}\text { Informasi } \\
\text { yang } \\
\text { diperoleh }\end{array}$ & Baik & Cukup & kurang & \\
\hline 1. & Ya & 1 & 10 & 3 & 14 \\
2. & Tidak & 5 & 16 & 10 & 31 \\
& Total & 6 & 26 & 13 & 45 \\
\hline
\end{tabular}

Tabel.9

Tabulasi Silang Pengetahuan dengan Sumber Informasi

\begin{tabular}{|c|c|c|c|c|c|}
\hline $\mathrm{N}$ & Sumber & \multicolumn{3}{|c|}{ Pengetahuan } & Total \\
\hline o & Informasi & Baik & Cukup & Kurang & \\
\hline 1. & Media Cetak & 0 & 3 & 2 & 5 \\
\hline 2. & $\begin{array}{l}\text { Media } \\
\text { Elektronik }\end{array}$ & 5 & 4 & 1 & 10 \\
\hline 3. & $\begin{array}{l}\text { Tenaga } \\
\text { Kesehatan }\end{array}$ & 0 & 8 & 7 & 15 \\
\hline 4. & $\begin{array}{l}\text { Teman, } \\
\text { Saudara, } \\
\text { Tetangga }\end{array}$ & 0 & 0 & 1 & 1 \\
\hline & Total & 5 & 15 & 11 & 31 \\
\hline
\end{tabular}

Berdasarkan hasil penelitian yang dilakukan peneliti pada tanggal 21-25 Mei 2015 di Poli Klinik Paru RSUD Arifin Achmad Propinsi Riau dengan judul "Gambaran Pengetahuan Pasien Tuberkulosis Paru Tentang Kepatuhan Minum Obat di Poli Klinik Paru RSUD Arifin Achmad Propinsi Riau“. Menurut hasil yang diperoleh dari penelitian ini dinyatakan bahwa pengetahuan responden dalam kategori baik sebanyak 6 responden $(13,3 \%)$, kategori cukup sebanyak 26 responden $(57,8)$, dan kategori kurang sebanyak 13 responden $(28,9 \%)$.

Menurut hasil di atas dapat diketahui bahwa kategori pengetahuan responden tentang kepatuhan minum obat mayoritas berpengetahuan cukup sebanyak 26 responden $(57,8 \%)$. Peneliti berasumsi bahwa hal ini berkaitan dengan informasi yang mayoritas responden pernah mendapatkan informasi yaitu sebanyak 16 responden $(61,5 \%)$, dan sumber informasi yang diperoleh yang mayoritas didapatkan dari tenaga kesehatan yaitu sebanyak 8 responden $(30,8 \%)$.

Peneliti berasumsi bahwa informasi yang diperoleh responden sangat mempengaruhi pengetahuan responden. Semakin banyak informasi yang didapat, maka semakin banyak pula pengetahuan responden, sehingga ia mampu berpikir lebih kritis di bandingkan dengan seseorang yang sedikit pengetahuan.

Sesuai dengan pendapat Suriyanto (2007), mengatakan informasi adalah salah satu organ pembentuk pengetahuan dan memegang peranan besar dalam membangun pengetahuan. Semakin banyak orang memperoleh informasi, maka semakin baik pula pengetahuannya, sebaliknya 
semakin kurang informasi yang diperoleh maka semakin kurang pula pengetahuannya.

Berdasarkan penelitian Simanullang (2012) yang berjudul Gambaran Pengetahuan Penderita TB Paru tentang Regimen Terapeutik TB Paru di Rumah Sakit Umum Herna Medan dengan 25 sampel, di dapatkan 18 responden (72\%) tidak pernah mendapatkan informasi mengenai regimen terapeutik, dan mayoritas berpengetahuan cukup yaitu sebanyak 15 responden $(70 \%)$.

Hal ini juga didukung oleh penelitian Kusuma (2014) yang berjudul gambaran tingkat pengetahuan pasien TB mengenai pelayanan kesehatan yang menggunakan strategi DOTS di Instalasi Rawat Jalan Rumah Sakit Jember dengan 21 sampel, didapatkan bahwa terdapat 12 responden $(57,14)$ belum pernah mendapatkan informasi mengenai hal yang diteliti, dan hasil penelitian yang di dapat mayoritas cukup dengan jumlah 15 responden $(71,42 \%)$.

Selain faktor informasi responden yang sudah dipaparkan di atas, faktor lain yang juga memegang peranan penting adalah sumber informasi yang didapatkan responden. Berdasarkan penelitian ini sumber informasi yang didapatkan responden mayoritas berasal dari tenaga kesehatan yaitu sebanyak 15 responden $(48,0 \%)$.

Peneliti berpendapat bahwa kebenaran informasi yang kita dapat juga berpengaruh pada sumber yang kita peroleh, semakin jelas sumber yang kita dapat maka semakin jelas pula informasi yang kita dapatkan, sehingga dalam meningkatkan kesehatan dapat tercapai secara optimal.

Menurut pendapat Roesli (2001), yaitu informasi atau penyuluhan kesehatan merupakan suatu usaha untuk membantu individu atau masyarakat dalam meningkatkan kemampuan untuk mencapai kesehatan yang optimal.

Menurut Notoatmodjo (2003) pengetahuan juga terbentuk dari informasi yang didapat dari pendidikan non formal seperti, membaca buku, Koran dan majalah serta menonton televisi dan mendengarkan radio.
Selanjutnya harus diperhatikan pula bahwa masih ada responden yang dengan tingkat pengetahuan rendah sebanyak 13 responden $(38,9 \%)$ yang dapat memberikan akibat pada ketidakpatuhan pasien TB dalam meminum obat, karena tidak memahami pentingnya minum obat serta patuh sesuai dengan resep yang diberikan. Hal ini terlihat pada data yang didapatkan pada survey awal sebelumnya tahun 2013 sebanyak 30 orang $(16,7 \%)$ dan tahun 2014 sebanyak 43 orang $(40,18 \%)$ dan adanya kasus akibat ketidak patuhan tersebut berefek pada munculnya penderita TB MDR (Multi Drug Resisten), yaitu suatu kondisi penderita TB yang mengalami resisten terhadap obat TB yang sebelumnya telah diberikan, sehingga perlu diberikan obat lainnya yang memerlukan dosis yang lebih besar dan butuh biaya yang lebih besar, kemudian penderita TB MDR tingkay penyebarannya lebih tinggi dan berbahaya bagi orang lain.

Menurut Syahrini (2008) menyatakan bahwa terdapat beberapa factor penyebab terjadinya resisten obat TB antara lain:

a. Pemakainan obat tunggal dalam pengobatan tuberculosis

b. Penggunaan panduan obat yang tidak adekuat, aitu jenis obatnya yang kurang atau di lingkungan tersebut telah terdapat resistensi yang tinggi terhadap obat yang digunakan, misalnya memberikan rifampisin dan INH saja pada daerah dengan resisten terhadap kedua obat tersebut sudah cukup tinggi

c. Pemberian obat yang tidak teratur, misalnya hanya dimakan dua atau tiga minggu lalu berhenti, setelah dua bulan berhenti kemudian berpindah dokter mendapat obat kembali selama dua atau tiga bulam behhenti kembali, demekian selanjutnya.

d. Fenomena "addition syndrome" yaitu suatu obat ditambahkan dalam suatu paduan pengobatan yang tidak berhasil. Bila kegagalan it terjadi karena kuman TB telah resisten pada panduan yang pertama, makan penambahan satu macam obat hanya akan menambah panjangnya obat yang resisten saja. 
e. Penggunaan obat kombinasi yang pencamprannya tidak dilakukan secara baik sehingga mengganggu bioavailabilitas obat.

f. Penyediaan obat yang tidak regular, kadangkadang terhenti pengirimannya sampai berbulan-bulan.

\section{KESIMPULAN DAN SARAN Kesimpulan}

Tuberkulosis paru adalah penyakit yang disebabkan oleh kuman Mycobacteriun tuberculosis yang ditularkan melalui udara (Widoyono, 2008).

Berdasarkan hasil penelitian yang dilakukan di Poli Klinik Paru RSUD Arifin Achmad Propinsi Riau pada tanggal 21-25 Mei 2015 dengan cara menyebarkan kuesioner yang berisikan 20 pernyataan sesuai dengan masalah yang diteliti, maka dapat di simpulkan, bahwa gambaran pengetahuan pasien TB paru tentang kepatuhan minum obat di Poli Klinik Paru RSUD Arifin Achmad Propinsi Riau mayoritas dalam kategori cukup yaitu sebanyak 26 responden $(57,78 \%)$. Hal ini dipengaruhi oleh faktor informasi dan sumber informasi.

\section{Saran}

Berdasarkan dari hasil penelitian tersebut terdapat beberapa saran yang dapat di sampaikan peneliti antara lain:

1. Kepada Peneliti Selanjutnya

Hasil penelitian ini diharapkan dapat menambah pengalaman bagi peneliti khususnya tentang kepatuhan minum obat pada TB paru dan bisa menjadi langkah awal untuk melakukan penelitian selanjutnya.

2. Kepada Pihak Institusi Pendidikan UMRI

Diharapkan untuk dapat menambah buku-buku di perpustakaan khususnya tentang Pengobtan TB paru dan menyediakan media informasi lainnya, sehingga mahasiswa lebih mudah untuk mendapatkan bahan dalam penelitian selanjutnya.

3. Kepada Pasien

Diharapkan pada pasien TB paru agar meningkatkan pengetahuan mengenai kepatuhan minum obat sehingga pasien dapat menerima pengetahuan dan lebih teliti dalam menjalani pengobatan.

\section{DAFTAR PUSTAKA}

Depkes. (2002). Diakses pada tanggal 12 April 2015. Di http://pppl.depkes.go.id/_asset/ regulasi/STRANAS_TB.pdf

Departemen Kesehatan Republik Indonesia. (2008). Tuberkulosis. Diakses dari http//www.ppm_plp.depkes.co.id/detil pada tanggal 22 Maret 2015.

Dinkes Propinsi Riau. (2012). Profil Kesehatan Pfopinsi Riau Tahun 2012. Pekanbaru.

Djojodibroto, Dr, R, Darmanto (2009). Respirologi (respiratory medicine). Jakarta EGC

Kusuma, F. Putera. (2014). Gambaran Tingkat Pengetahuan Pasien TB Mengenai Pelayanan Kesehatan Yang Menggunakan Strategi DOTS Di Instalasi Rawat Jalan Rumah Sakit Jember. Universitas Jember.

Muniarsih, E., \& Levina. (2008). Hubungan pemberian imunisasi BCG dengan kejadian tuberculosis paru pada anak balita dibalai pengobatan penyakit paruparu Ambarawa tahun 2007. Diakses pada tanggal 15 april dari www. 10 JOM PSIK VOL.1 NO 2 Tuberkulosis paru.com.doc.pdf

Niven, N. (2012). Psikologi kesehatan: Pengantar untuk perawat \& professional kesehatan lain. Jakarta: EGC

Notoatmodjo. (2003). Ilmu Kesehatan Masyarakat. Jakarta: Rineka Cipta

Notoatmodjo. (2005). Metodologi Penelitian Kesehatan. Jakarta: PT Rineka Cipta.

Parhusip, M. Bobby E. (2009). Peranan Foto Dada Dalam Mendiagnosis Tuberkulosis Paru Tersangka Dengan BTA Negatif Di Puskesmas Kodya Medan. FK USU: Medan.

Roesli. (2001). Petunjuk untuk Tenaga Kesehatan Biomed. Jakarta: Rineka Cipta

Setiadi. (2007). Konsep dan Penulisan Riset Keperawatan. Yogyakarta: Graha Ilmu.

Simanulang, Poniyah.(2012). Gambaran Pengetahuan Penderita TB Paru tentang Regimen Terapeutik TB Paru di 
Rumah Sakit Umum Herna Medan. UDA: Medan.

Soemantri, Irman. (2007). Keperawatan Medikal Bedah: Asuhan Keperawatan Dengan Gangguan Sistem Pernapasan. Salem Medika: Jakarta.

Syahrini. DR Henny. (2008). Tuberkulosis Paru Resisten Ganda. USU: Medan
Wikipedia. (2010). Diakses pada tanggal 12 April 2015 di http://wikipedi. 2010.html//.

WHO. (2013). Defenition and diagnosis of pulmonolgy tuberculosis. Diakses darihttps://mdgsgoals.com.who.int/sree/ pada tanggal 27 Desember 2007.

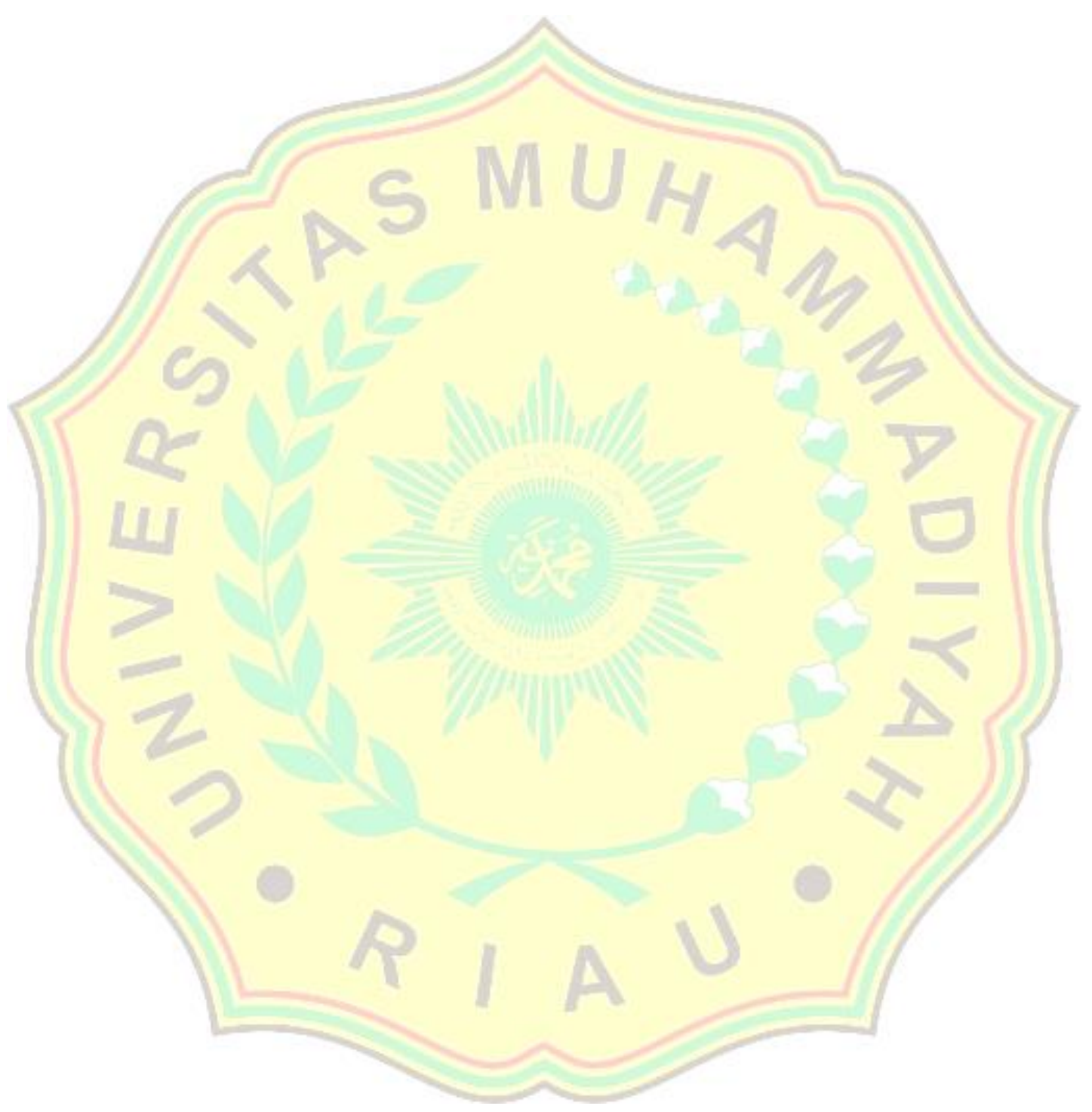

